\title{
《辐射研究与辐射工艺学报》 第七届期刊编辑委员会成立暨第一次会议纪要
}

在2019年 “辐射化学与辐射技术研讨会” 暨中国核学会辐射应用分会理事会期间（2019年10月24 27 日, 安徽池州) , 《辐射研究与辐射工艺学报》召开了第七届期刊编辑委员会成立暨第一次会议。来自中 国科学院上海应用物理研究所、中国科学技术大学、北京大学、厦门大学、苏州大学、南京航空航天大学、 中国辐射防护研究院、中国科学院新疆理化技术研究所、上海市计量测试技术研究院、空军军医大学、军 事医学科学院放射与辐射医学研究所等单位的吴国忠、李景烨、葛学武、张志成、翟茂林、刘芬菊、眭国 平、杨仲田、马骏、林铭章、彭静、汪谟贞、王谋华、许零、陈英、孙静、谢学军等编委代表, 以及联合 编辑部主任李勇平、编辑赵翠兰、付雅静等出席了会议, 部分分会青年理事和审稿专家也列席了本次会议。

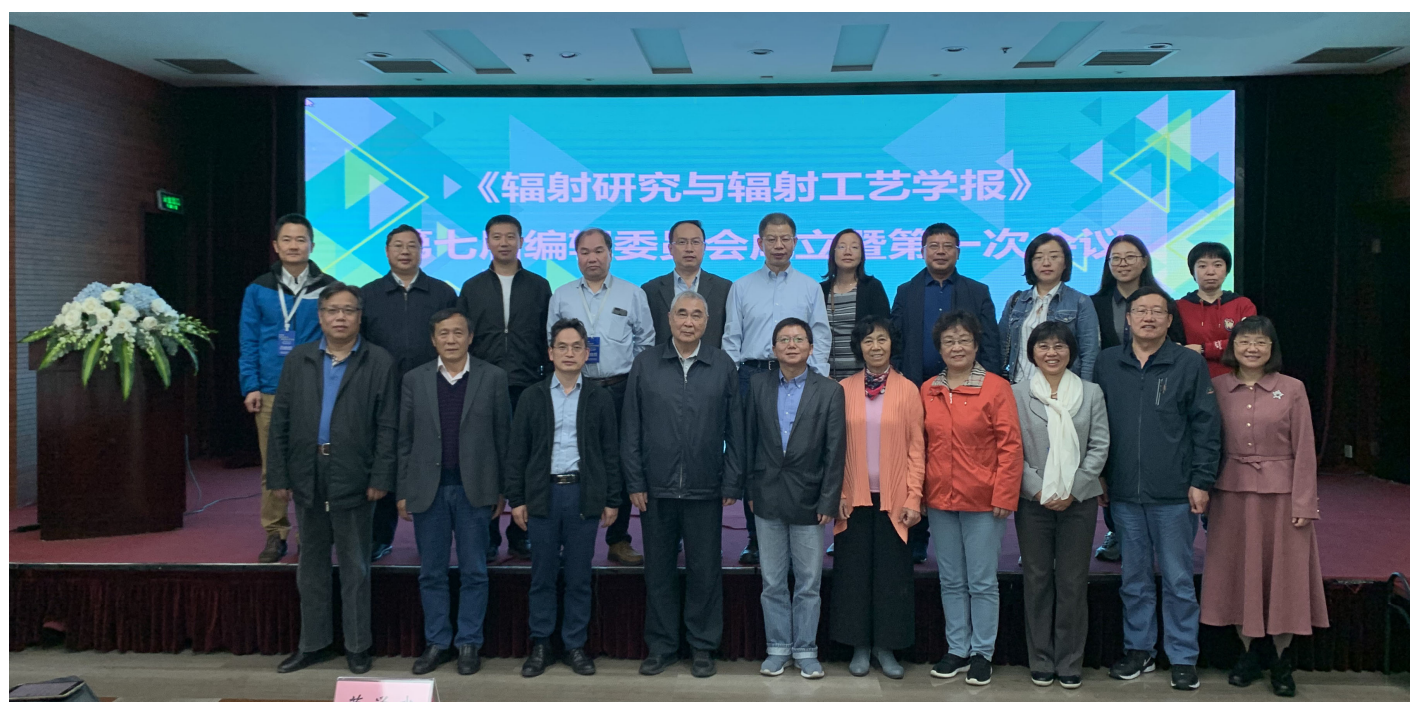

联合编辑部主任李勇平研究员在会上做了主题报告，首先介绍了期刊的基本情况、计量指标、第六届 编委会所做的工作、取得的成绩以及近两年编委成员对期刊的贡献数据。第六届编委会在主编李景烨研究 员的带领下，经过全体人员的共同努力，期刊指标得到了显著提升：影响因子和综合评价在《中国科技期 刊引证报告》中连续4年保持 “核科学与技术” 类期刊排名第一; 在CNKI数据库 “核科学与技术” 类期刊 中的引证指标, 期刊影响力从2013年第9位上升到2016年第6位后保持至今, 影响因子排名上升到第一位; 在CSCD “核科学与技术” 类期刊的影响因子排名也从第6位上升到第2位; 学报在2017年入选了 “中国精 品科技期刊” ，并获2017年度 “百杰期刊” 荣誉。李勇平主任代表主办单位对第六届编委会的辛勤努力和 取得的显著成绩表示了衰心的感谢，同时通报了主办单位更换主编的原因以及聘请吴国忠研究员担任新一 届编委会主编的决议，并就期刊编委会及编委的基本职责和编委会运行机制进行了说明。新任主编吴国忠 研究员表示: 感谢主办单位的信任, 将尽心尽力把工作做好; 建议学报与日本相关期刊加强合作, 将优秀 的日文专业论文介绍到国内, 并希望新一届编委会委员能为增加稿源、提高稿件质量、扩大刊物影响力做 出自己的一份贡献。 
随后的会议讨论中, 参会代表踊跃发言, 气氛热烈。李勇平主任总结时表示, 参考国内优秀期刊的办 刊经验, 可以组建青年编辑委员会; 为保持编辑委员会活力和调动编委积极性, 编委会将保持开放状态, 任期内不定期更替; 如果稿源状况改善, 首先考虑扩大期刊发文量, 在做强的同时把期刊做大; 要积极推 进期刊的公众号平台宣传, 已招聘专业人员负责, 希望大家踊跃提供素材。编辑部将充分考虑与会专家的 意见, 争取得到主办单位在约稿、版面费减免等方面的支持, 努力将刊物办得更好。最后, 吴国忠主编强 调了科学家办刊的必要性, 表示《辐射研究与辐射工艺学报》将逐渐向科学家办刊模式转型。

\section{《辐射研究与辐射工艺学报》第七届编委会及顾问名单}

\begin{tabular}{|c|c|c|c|c|}
\hline \multirow{3}{*}{ 顾 问 } & 郭国祯 & 第四军医大学 & 金一尊 & 复旦大学 \\
\hline & 周瑞敏 & 上海大学 & 哈益明 & 中国农业科学院农产品加工研究所 \\
\hline & 张志成 & 中国科学技术大学 & 林万敏 & 上海大学 \\
\hline \multirow{4}{*}{$\begin{array}{l}\text { 主 编 } \\
\text { 副主编 }\end{array}$} & 吴国忠 & 中国科学院上海应用物理研究所 & & \\
\hline & 曹建平 & 苏州大学 & 李勇平 & 中国科学院上海应用物理研究所 \\
\hline & 葛学武 & 中国科学技术大学 & 马 骏 & 南京航空航天大学 \\
\hline & 李景烨 & 上海师范大学 & 王克勤 & 湖南省农业科学研究院 \\
\hline \multirow[t]{17}{*}{ 委 员 } & 陈洪兵 & 中国工程物理研究院 & 眭国平 & 上海计量测试研究院 \\
\hline & 陈 捷 & 上海大学 & 孙 静 & 中国科学院新疆理化技术研究所 \\
\hline & 陈 英 & 军事医学科学院 & 汪谟贞 & 中国科学技术大学 \\
\hline & 邓 波 & 武汉纺织大学 & 王锋超 & 第三军医大学 \\
\hline & 邓鹏飏 & 中国科学院长春应用化学所 & 王谋华 & 中国科学院上海应用物理研究所 \\
\hline & 傅俊杰 & 浙江大学 & 吴李君 & 中国科学院合肥物质研究院 \\
\hline & 黄 玮 & 中国工程物理研究院 & 许 零 & 厦门大学 \\
\hline & 吉艳琴 & 中国疾病预防控制中心 & 杨仲田 & 中国辐射防护研究院 \\
\hline & 李林繁 & 中国科学院上海应用物理研究所 & 曾丽华 & 第四军医大学 \\
\hline & 李文建 & 中国科学院近代物理研究所 & 翟茂林 & 北京大学 \\
\hline & 李银涛 & 西南科技大学 & 张伯武 & 上海师范大学 \\
\hline & 林铭章 & 中国科技大学 & 赵弘蹈 & 黑龙江省科学院技术物理研究所 \\
\hline & 刘芬菊 & 苏州大学 & 赵 龙 & 上海交通大学 \\
\hline & 刘 卫 & 中国科学院上海应用物理研究所 & 卓维海 & 复旦大学 \\
\hline & 刘圆圆 & 北京师范大学 & \multirow{2}{*}{\multicolumn{2}{|c|}{ 陈进华（日本） }} \\
\hline & 彭＼cjkstart静 & 北京大学 & & \\
\hline & 邵春林 & 复旦大学 & \multicolumn{2}{|c|}{ 杨金峰（日本）日本大阪大学产业科学研究所 } \\
\hline
\end{tabular}

